\title{
Managing the Patient Being Treated with Biologic Agents for Rheumatic Disease: Pearls for the General Internist
}

\author{
Alfred A. Cividino MD FRCPC FACR
}

\section{About the Author}

Alfred A. Cividino is a professor and the division director, Division of Rheumatology, Department of Medicine, at McMaster University, in Hamilton, Ontario. Correspondence may be directed to civi@cogeco.ca.

$\mathrm{R}^{\mathrm{h}}$ heumatoid arthritis (RA) is a chronic polyarticular disease with systemic consequences leading to impairment and disability. Typical pharmacological treatment consists of nonsteroidal anti-inflammatory drugs and disease-modifying drugs such as methotrexate, sulfasalazine, hydroxychloroquine, and leflunomide. When disease activity persists, the next level of treatment is the biologic drugs. Some of these agents have been available since 1999. Currently, there are nine biologic drugs available for the treatment of RA. Some agents such as the tumour necrosis factor (TNF) inhibitors also have approved indications for psoriatic arthritis, ankylosing spondylitis, and inflammatory bowel disease.

Table 1 shows the nine currently available biologic agents and their indications, pharmacological characteristics, and modes of administration.

The most commonly used agents are the TNF inhibitors. The five agents in this category are all large molecules that require either intravenous or subcutaneous administration. While they all target TNF, they differ in several ways. The products adalimumab, infliximab, golimumab, and certolizumab are antibodies, but they may also bind membrane-bound TNF. Infliximab is the only TNF inhibitor that is administered intravenously. The other TNF inhibitors are either fully human or humanized. Infliximab is a chimeric monoclonal antibody. Immunogenicity with loss of efficacy can be seen when administered without methotrexate in patients with RA. Certolizumab is distinct in that it is a humanized PEGylated Fab fragment targeting TNF. While these agents are very effective, not all patients respond to TNF inhibition.

Currently, other therapeutic targets have been identified including T-cell activation, B-cells, and interleukin-6 (IL-6). Abatacept is a fully human fusion protein that blocks T-cell coactivation by antigen presenting cells. It is administered by infusion; however, a subcutaneous preparation may be available soon. Rituximab has been used for CD-20-positive lymphoma for many years. It is a chimeric antibody to CD-20-positive B cells. It is administered by two $1,000 \mathrm{mg}$ infusions 15 days apart. Infusions require pre-medication with steroids and antihistamines to minimize infusion-related reactions. Lastly, tocilizumab is a fully human monoclonal antibody targeting the IL-6 receptor and is administered by infusion monthly.

\section{Infliximab}

Infliximab is a chimeric antibody with a half-life of 8-9.5 days. In $\mathrm{RA}$, it is administered in a dose of $3 \mathrm{mg} / \mathrm{kg}$ intravenously in combination with methotrexate. Loading doses are required at 2 and 6 weeks and then every 8 weeks. For severe disease, doses of $10 \mathrm{mg} / \mathrm{kg}$ every 4 weeks may be required, though cost-effectiveness is diminished. For patients with psoriatic arthritis and ankylosing spondylitis, dosing is $5 \mathrm{mg} / \mathrm{kg}$ at baseline and 2 and 6 weeks, and then every 8 weeks. In this population, infliximab is effective as monotherapy. ${ }^{1-4}$

\section{Etanercept}

Etanercept is a fully human fusion protein TNF receptor antagonist that binds soluble TNF and lymphotoxin- $\alpha$. It is administered subcutaneously at $50 \mathrm{mg}$ once or $25 \mathrm{mg}$ twice weekly. The half-life is 4 days. Etanercept can be used as monotherapy but is typically used in combination with methotrexate. The Trial of Etanercept and Methotrexate with Radiographic Patient Outcomes (TEMPO) study found superior efficacy for etanercept when combined with methotrexate. ${ }^{5}$

In order to control psoriasis, a dose of $50 \mathrm{mg}$ twice weekly is used for the initial 12 weeks. Etanercept is similarly effective in psoriatic arthritis and ankylosing spondylitis., 
Table 1. Biologics' Product Characteristics

\begin{tabular}{|c|c|c|c|c|c|c|}
\hline & Adalimumab & Etanercept & Infliximab & Certolizumab & Golimumab & Abatacept \\
\hline Trade name & HUMIRA & Enbrel & Remicade & Cimzia & Simponi & Orencia \\
\hline Company & AbbVie & Amgen & $\begin{array}{l}\text { Centocor Inc. } \\
\text { Janssen }\end{array}$ & UCB & Janssen & $\begin{array}{l}\text { Bristol-Myers } \\
\text { Squibb }\end{array}$ \\
\hline Molecule type & $\begin{array}{l}\text { Fully human } \\
\text { monoclonal } \\
\text { antibody }\end{array}$ & $\begin{array}{l}\text { Fully human } \\
\text { fusion protein }\end{array}$ & $\begin{array}{l}\text { Chimeric } \\
\text { monoclonal } \\
\text { antibody }\end{array}$ & $\begin{array}{l}\text { Humanized } \\
\text { PEGylated Fab } \\
\text { fragment }\end{array}$ & $\begin{array}{l}\text { Fully human } \\
\text { monoclonal } \\
\text { antibody }\end{array}$ & $\begin{array}{l}\text { Fully human } \\
\text { fusion protein }\end{array}$ \\
\hline Target & TNF- $\alpha$ & TNF- $\alpha$ & TNF- $\alpha$ & TNF- $\alpha$ & TNF- $\alpha$ & T cell \\
\hline Dosing & $40 \mathrm{mg} \mathrm{EOW}$ & $\begin{array}{l}50 \mathrm{mg} / \mathrm{mL} \text { q1w } \\
\text { or } 25 \mathrm{mg} / \mathrm{mL} \text { q2w }\end{array}$ & $3-7.5 \mathrm{mg} / \mathrm{kg} \mathrm{q} 8 \mathrm{w}$ & $\begin{array}{l}200 \mathrm{mg} \mathrm{q} 2 \mathrm{w} \\
\text { or } 400 \mathrm{mg} \text { q4w } \\
\text { EOW most probable }\end{array}$ & 50 mg monthly & $\begin{array}{l}125 \mathrm{mg} / \mathrm{mL} \text { weekly } \\
\text { following a single IV } \\
\text { loading dose }\end{array}$ \\
\hline Delivery method & $\begin{array}{l}\text { Self-injection SC } \\
\text { (PFS and pen) }\end{array}$ & $\begin{array}{l}\text { Self-injection SC } \\
\text { (PFS and pen) }\end{array}$ & 120-minute infusion & Self-injection SC & $\begin{array}{l}\text { Self-injection SC } \\
\text { (pen) }\end{array}$ & $\begin{array}{l}\text { 30-minute infusion, } \\
\text { self-injection SC }\end{array}$ \\
\hline Indication & $\begin{array}{l}\text { RA, JIA, AS, PsA, } \\
\text { Ps, Crohn's }\end{array}$ & RA, JIA, AS, PsA & $\begin{array}{l}\text { RA, AS, Crohn's, } \\
\text { UC, PsA, Ps }\end{array}$ & RA & RA, AS, PsA & RA, JIA \\
\hline
\end{tabular}

$\mathrm{AS}=$ ankylosing spondylitis; EOW = every other week; IL = interleukin; JA = juvenile idiopathic arthritis; PFS = prefilled syringe; Ps = psoriasis;

PsA = psoriatic arthritis; RA = rheumatoid arthritis; SC = subcutaneous; TNF = tumour necrosis factor; UC = ulcerative colitis.

Source: Data mostly from the Canadian Pharmacists Association; Compendium of Pharmaceuticals and Specialties; Ottawa (ON): The Association; 2011.

\section{Adalimumab}

Adalimumab is a human monoclonal antibody that binds both soluble and membrane-bound TNF. The half-life is 12 days. The typical dose is $40 \mathrm{mg}$ subcutaneously every other week. While effective as monotherapy, its efficacy is enhanced in combination with methotrexate in RA and PsA. ${ }^{8}$ Adalimumab is also effective as monotherapy in psoriatic arthritis and ankylosing spondylitis. ${ }^{9,10}$

\section{Golimumab}

Golimumab is a human monoclonal antibody with specificity for TNF. Its half-life is 14 days, but it is administered every 4 weeks as a $50 \mathrm{mg}$ dose subcutaneously.

This agent has been shown to be effective in the treatment of RA, psoriatic arthritis, and ankylosing spondylitis. ${ }^{11-13}$

\section{Certolizumab Pegol}

Certolizumab pegol is a humanized PEGylated Fab fragment antiTNF monoclonal antibody. The Fab antibody portion is fused to polyethylene glycol (PEG) molecule. This PEGylation process delays the clearance of the molecule, resulting in a half-life of 14 days. Standard dosing is $400 \mathrm{mg}$ at weeks 0,2 , and 4, and then 200 mg weekly administered subcutaneously.

Efficacy has been shown in RA with or without methotrexate..$^{14,15}$

\section{Tocilizumab}

Tocilizumab is a humanized antihuman antibody targeting the IL-6 receptor (IL-6R). The drug is administered intravenously at $4 \mathrm{mg} / \mathrm{kg}$ or $8 \mathrm{mg} / \mathrm{kg}$ monthly. ${ }^{16,17}$ A large research program has shown tocilizumab to be effective in treating signs and symptoms of RA as well as retarding radiographic progression. Tocilizumab has also been shown to be effective as monotherapy and, in one trial, was found to be superior to methotrexate. ${ }^{17,18}$

Infections occur at similar rates to other biologic diseasemodifying anti-rheumatic drugs (DMARDs). The most common infections reported have been cellulitis, pneumonia, gastroenteritis, diverticulitis, sepsis, and bacterial arthritis. ${ }^{19}$ Abnormal liver function ( $>3 \times$ normal levels) has been noted when tocilizumab is used in combination with DMARDs (5-6\%) but less often with monotherapy $(1 \%) .{ }^{20}$ Neutrophil count below $1,000 / \mathrm{mm}^{3}$ occurred in up to $3.4 \%$ with tocilizumab plus DMARD compared with $0.1 \%$ in placebo plus DMARD in 24-week controlled trials. There did appear to be a relationship between neutropenia and serious infections. ${ }^{19}$ No increased incidence of malignancy, tuberculosis reactivation, or hepatitis was seen. Rare events including gastrointestinal perforation related to diverticular disease were noted, but confounders were the use of steroids, non-steroidal anti-inflammatory drugs, and methotrexate.

\section{Rituximab}

Rituximab has proven to be a novel therapy in treating RA. Rituximab is a chimeric monoclonal antibody targeting a B-cell surface marker CD20. With a single rituximab infusion, B cells are rapidly depleted from the peripheral blood and, subsequently, synovial tissues in most but not all patients. ${ }^{21}$

The treatment regimen is a course of $1,000 \mathrm{mg}$ given on days 1 and 15, together with methotrexate. Clinical response is most robust in rheumatoid factor-positive patients. The mean duration of response or retreatment interval is 6-12 months. ${ }^{22-24}$

While B-cell depletion therapy has been associated with some reduction in immunoglobulin levels, this has not been 


\begin{tabular}{|c|c|c|}
\hline Rituximab & Tocilizumab & Anakinra \\
\hline Rituxan & Actemra & Kineret \\
\hline Roche & Roche & Sobi \\
\hline Biogen Idec & Chugai & \\
\hline $\begin{array}{l}\text { Chimeric } \\
\text { monoclonal } \\
\text { antibody }\end{array}$ & $\begin{array}{l}\text { Humanized } \\
\text { monoclonal } \\
\text { antibody }\end{array}$ & $\begin{array}{l}\text { Monoclonal antibody } \\
\text { (IL-1 receptor } \\
\text { antagonist) }\end{array}$ \\
\hline B cell & IL-6R & IL-1 receptor \\
\hline $\begin{array}{l}1,000 \mathrm{mg} \text { IV q2w } \\
\text { Subsequent infusions } \\
\text { repeated as necessary }\end{array}$ & 4 or $8 \mathrm{mg} / \mathrm{kg}$ monthly & $100 \mathrm{mg}$ daily \\
\hline $\begin{array}{l}195-\text { to } 255- \\
\text { minute infusion }\end{array}$ & 60-minute infusion & Self-injection SC \\
\hline RA & RA & $\begin{array}{l}\text { Rarely used in RA now; } \\
\text { check package insert }\end{array}$ \\
\hline
\end{tabular}

associated with an increased infection risk in this population. Nonetheless, current recommendations are that all recommended vaccines should be given prior to treatment to improve efficacy. Vaccination administered in close proximity to rituximab use is less effective. ${ }^{25,26}$ The overall rate of serious infection reported in a longitudinal safety study was 4.31 infections/100 patient-years, consistent with rates seen with other biologic DMARDs. Viral reactivation, a concern with Bcell depletion, was not increased in this population. Progressive multifocal leukoencephalopathy (PML), a rare disease caused by reactivation by the JC virus, was reported in one patient who also received cancer chemotherapy. ${ }^{27}$

Overall there was no excess mortality, cardiovascular events, tuberculosis (TB), or evidence of malignancy reported. Repeated courses of treatment did not result in any increase in serious adverse events. ${ }^{27}$

\section{Abatacept}

Abatacept is a fully human fusion protein (cytotoxic Tlymphocyte-associated antigen 4-immunoglobulin G1 [CTLA4Ig]) whose mode of action is to block T-cell activation. This is accomplished by binding to CD80 and CD86 on antigen presenting cells, thus blocking their binding with CD28 on $\mathrm{T}$ cells and their subsequent activation.

Abatacept is administered intravenously in a dose of 10 $\mathrm{mg} / \mathrm{kg}$ over 30 minutes. Infusion reactions are uncommon and infusion can be undertaken in the home or infusion centre. ${ }^{28}$

\section{Summary}

A recent meta-analysis showed that there is significant efficacy for the approved biologic drugs compared with placebo, based
Table 2. Meta-analysis of Efficacy with Biologics in RA: ACR50

\begin{tabular}{lccc} 
Biologic & No. of Studies & OR $(95 \%$ Cl) & Heterogeneity \\
\hline Abatacept & 6 & $2.98(1.79-4.97)$ & $I^{2}=0 \%$ \\
\hline Adalimumab & 8 & $3.70(2.40-5.70)$ & $I^{2}=77 \%$ \\
\hline Anakinra & 3 & $1.68(0.83-3.41)$ & $I^{2}=84 \%$ \\
\hline Etanercept & 4 & $4.97(2.70-9.13)$ & $I^{2}=75 \%$ \\
\hline Infliximab & 3 & $2.92(1.37-6.24)$ & $I^{2}=16 \%$ \\
\hline Rituximab & 3 & $4.10(2.02-8.33)$ & $I^{2}=17 \%$ \\
\hline Overall & 27 & $3.35(2.62-4.29)$ & $I^{2}=69 \%$
\end{tabular}

ACR50 $=50 \%$ improvement in the American College of Rheumatology symptomatic criteria; $\mathrm{Cl}=$ confidence interval $; \mathrm{OR}=$ odds ratio.

Source: Adapted from Singh et al. ${ }^{29}$

Table 3. Meta-Analysis of Efficacy with Biologics in RA: Safety*

\begin{tabular}{lccc} 
Biologic & No. of Studies & OR $(95 \% \mathrm{Cl})$ & Heterogeneity \\
\hline Abatacept & 6 & $1.24(0.88-1.76)$ & $I^{2}=15 \%$ \\
\hline Adalimumab & 8 & $1.54(1.12-2.12)$ & $I^{2}=0 \%$ \\
\hline Anakinra & 5 & $1.67(1.22-2.29)$ & $I^{2}=0 \%$ \\
\hline Etanercept & 4 & $0.82(0.56-1.19)$ & $I^{2}=94 \%$ \\
\hline Infliximab & 3 & $2.21(1.28-3.82)$ & $I^{2}=55 \%$ \\
\hline Rituximab & 3 & $1.34(0.65-2.76)$ & $I^{2}=0 \%$ \\
\hline Overall & 29 & $1.39(1.13-1.71)$ & $I^{2}=15 \%$ \\
\hline
\end{tabular}

$\mathrm{Cl}=$ confidence interval; $\mathrm{OR}=$ odds ratio.

* Placebo is safer.

Source: Adapted from Singh et al. ${ }^{29}$

on demonstrating at least a 50\% improvement in patient and physician reported criteria of the American College of Rheumatology (ACR 50). The study also showed that placebo is safer for all agents except etanercept (odds ratio 0.82) based on withdrawals for adverse events. ${ }^{29}$

These agents have all been shown to retard radiographic progression, a hallmark of future disability in RA. ${ }^{30}$ Table 2 presents the efficacy of biologics in RA related to a 50\% improvement in the American College of Rheumatology symptomatic criteria (ACR50). Table 3 presents the efficacy of biologics related to safety.

\section{Clinical Considerations Infections in Patients Using Biologic Drugs}

Overall, the risk of infections is greater in patients taking biologic drugs..$^{29}$ Abatacept seems to be less of a concern; however, the product monograph warns about increased pulmonary complications, including infections in those with chronic obstructive lung disease (COPD). The risk for infection seems to be greatest in those beginning treatment, and it decreases after the first year. ${ }^{31,32}$ 
When a patient using a biologic agent presents with infection, discontinuing the agent is prudent. One must recognize that the half-life of these agents varies from 4 days for etanercept to 12-14 days for adalimumab, golimumab, and certolizumab. Most infections respond to treatment before complete clearance of the drug is achieved.

The types of infections seen in patients on biologic therapy mirror those seen in the general population. Opportunistic infections with Mycobacterium tuberculosis are of concern, as disseminated disease or reactivation of latent disease is seen in all clinical trials with the TNF antagonists. It is important to consider other risk factors for TB such as country of origin or travel to countries where TB is endemic, or specific at-risk populations (e.g., Aboriginal). Screening is recommended for all patients prior to the use of the anti-TNF therapies abatacept and tocilizumab. ${ }^{33}$ While other opportunistic infections have been reported with biologic agents, disease severity, the use of corticosteroids, and co-morbidities contribute to this risk. ${ }^{34}$

\section{Perioperative Care}

When elective surgery is being considered in patients on immunosuppressive therapy, infection risk may be increased. Concomitant medications such as methotrexate and corticosteroids may increase the risk for infection and impair wound healing. The merits of discontinuing treatment must be balanced against the risk of disease flares.

The Canadian Rheumatology Association guidelines recommend that biologic drugs be held prior to surgical procedures. The timeline must take into consideration the individual patient, the nature of the surgery, and the drug's halflife. The biologic can be resumed in the absence of infection and if wound healing is satisfactory. ${ }^{33}$

The American College of Rheumatology recommends that biologics should not be used 1 week prior to and 1 week after surgery, taking into consideration the pharmacokinetics of the agent and the infectious risk of the surgery. ${ }^{35}$

The British Society of Rheumatology recommends the following: "Treatment with infliximab, etanercept and adalimumab should be withheld for 2 to 4 weeks prior to major surgical procedures. Treatment may be restarted postoperatively if there is no evidence of infection and once wound healing is satisfactory." 36

\section{Cardiovascular Risk}

A number of publications have highlighted the increased cardiovascular risk inherent in patients with RA. The estimated risk is 1.5 - to 2 -fold and is similar to that in patients with diabetes mellitus. ${ }^{37}$
Recently, the use of TNF inhibitors has been shown to reduce the incidence of cardiovascular events. The true benefit was most evident in treatment responders, suggesting that control of inflammation is responsible for the risk reduction. ${ }^{37,38}$

Those individuals at risk of heart failure or who have New York Heart Association class III or IV heart failure should not receive TNF inhibitors. TNF is increased in CHF, and studies using infliximab for CHF showed increases in exacerbation of CHF and in death. ${ }^{39,40}$

\section{Malignancy Risk}

The issue of malignancy risk has been closely scrutinized in clinical trials, registries, and meta-analyses. Patients with RA are at a higher risk for lung cancer and lymphoma. ${ }^{41}$ The risk of lymphoma correlates with disease activity. With respect to biologic agents, all but one meta-analysis showed no increase in malignancies, including lymphomas. Rare cases of hepatosplenic lymphoma have been reported in patients with inflammatory bowel disease, in association with infliximab and adalimumab use. Observational studies have reported increased frequencies of nonmelanoma skin cancers. ${ }^{42-45}$

\section{Viral Complications}

Several databases in Spain, Germany, and Canada have reported higher risks of varicella infection in patients with RA. ${ }^{46-48}$ TNF inhibitors and rituximab are associated with an increased risk of hepatitis $\mathrm{B}$ reactivation. There are rare reports of PML in patients using rituximab. Of 57 reported cases, most were related to the use of rituximab for chemotherapy. There were two cases in patients with systemic lupus erythematosus (SLE) and one case involving a patient with RA. There is no screening or treatment available for this rare but fatal condition. ${ }^{49}$

\section{Vaccination}

The risks of infections and associated mortality can be mitigated by the prior use of vaccination in patients prescribed biologic agents to maximize their effectiveness. In the case of rituximab, if immunization is not achieved pre-treatment, then a delay in immunization offers better protection. ${ }^{50,51}$

The Canadian Rheumatology Association guidelines recommend annual influenza vaccination and pre-treatment vaccination against pneumococcal disease with inactivated/ killed vaccines. For high-risk populations, hepatitis B vaccination is recommended. Currently, the herpes zoster vaccine is a live vaccine and is to be avoided in patients who are using biologic agents. ${ }^{33}$ An inactivated vaccine is in development, so this recommendation may change. 


\section{Conclusion}

The following is a summary of key points related to the use of biologics:

- Biologic agents are effective in patients with rheumatic disease such as RA, psoriatic arthritis, and ankylosing spondylitis.

- Infection risk is greater for patients on biologic agents than on DMARDs alone, though co-morbid conditions and the use of corticosteroids play a role. Biologic agents should be held in the face of active infection.

- Screening for latent TB is recommended in all patients prior to treatment.

- TNF inhibitors and other biologic drugs should be held when surgery is considered; the duration depends on the half-life of the agents and time for wound healing.

- The risk of lymphoma in general is not increased with the use of TNF inhibitors, although rare cases of hepatosplenic lymphoma have been reported in patients with Crohn's disease.

- Vaccinations should be given prior to treatment with biologic agents. Live vaccines are to be avoided in patients on treatment.

\section{References}

1. Kavanaugh A, St. Clair EW, McCune WJ, et al. Chimeric anti-tumour necrosis factor $\alpha$ monoclonal antibody treatment of patients with rheumatoid arthritis receiving methotrexate therapy. J Rheumatol 2000;27:841-50.

2. St. Clair E, Wagner C, Fasanmade A, et al. Relationship of serum infliximab concentrations to clinical improvement in rheumatoid arthritis. Arthritis Rheum 2002;46:1451-9.

3. Antoni CE, Kavanaugh A, Kirkham B, et al. Sustained benefits of infliximab therapy for dermatologic and articular manifestations of psoriatic arthritis: results from the Infliximab Multinational Psoriatic Arthritis Controlled Trial (IMPACT). Arthritis Rheum 2005;52:1227-36.

4. Braun J, Brandt J, Listing J, et al. Treatment of active ankylosing spondylitis with infliximab: a randomised controlled multicentre trial. Lancet 2002;359:1187-93.

5. Klareskog L, van der Heijde D, de Jager JP, et al. Therapeutic effect of the combination of etanercept and methotrexate compared with each treatment alone in patients with rheumatoid arthritis: double-blind randomized controlled trial. Lancet 2004;363:675-81.

6. Mease PJ, Kivitz AJ, Burch FX, et al. Etanercept treatment of psoriatic arthritis: safety, efficacy, and effect on disease progression. Arthritis Rheum 2004;50:2264-72.

7. Davis JC, van der Heijde D, Braun J, et al. Sustained durability and tolerability of etanercept in ankylosing spondylitis for 96 weeks. Ann Rheum Dis 2005;64:1557-62.

8. Breedveld FC, Weisman MH, Kavanaugh AF, et al. The PREMIER study: a multicenter, randomized, double-blind clinical trial of combination therapy with adalimumab plus methotrexate versus methotrexate alone or adalimumab alone in patients with early, aggressive rheumatoid arthritis who had not had previous methotrexate treatment. Arthritis Rheum 2006;54:2637.

9. Mease PJ, Gladman DD, Ritchlin CT, et al. Adalimumab for the treatment of patients with moderately to severely active psoriatic arthritis: result of a double-blind, randomized, placebo-controlled trial. Arthritis Rheum 2005;52:3279-89.

10. Van der Heijde D, Kivitz A, Schiff M, et al. Efficacy and safety of adalimumab in patients with ankylosing spondylitis: results of a multicenter, randomized double-blind, placebo-controlled trial. Arthritis Rheum 2006;54:2136-46.

11. Kay J, Matteson EL, Dasgupta B, et al. Golimumab in patients with active rheumatoid arthritis despite treatment with methotrexate: a randomized, double-blind, placebo-controlled, dose ranging study. Arthritis Rheum 2008;58:964-75.

12. Kavanaugh A, McInnes J, Mease P, et al. Golimumab, a new human antiTNF $\alpha$ monoclonal antibody, administered every four weeks as a subcutaneous injection in psoriatic arthritis: twenty-four week efficacy and safety results of a randomized, placebo-controlled study. Arthritis Rheum 2009;60(4):976-86.

13. Inman RD, Davis JC Jr., van der Heijde D, et al. Efficacy and safety of golimumab in patients with ankylosing spondylitis: results of randomized double blind placebo-controlled phase III trial. Arthritis Rheum 2008;58:3402-12.

14. Keystone E, van der Heijde D, Mason D Jr., et al. Certolizumab pegol plus methotrexate is significantly more effective than placebo plus methotrexate in active rheumatoid arthritis. Arthritis Rheum 2008;11:3319-29.

15. Smolen JS, van Vollenhoven RF, Kavanaugh A, et al. Efficacy and safety of certolizumab pegol plus methotrexate in patients with rheumatoid arthritis: 3-year data from the RAPID 2 study. Arthritis Rheum 2010;62(10 Suppl): S753.

16. Jones G, Sebba A, Gu J, et al. Comparison of tocilizumab monotherapy versus methotrexate monotherapy in patients with moderate to severe rheumatoid arthritis. The AMBITION study. Ann Rheum Dis 2010;69:88-96.

17. Smolen JS, Beulieu A, Rubbert-Roth A, et al. Effect of interleukin-6 receptor inhibition with tocilizumab in patients with rheumatoid arthritis (OPTION study): a double-blind, placebo-controlled, randomized trial. Lancet 2008;371:987-97.

18. Kremer JM, Blanco R, Brzosko M, et al. Tocilizumab inhibits structural joint damage in rheumatoid arthritis patients with inadequate responses to methotrexate: results from the double-blind treatment phase of a randomized placebo-controlled trial of tocilizumab safety and prevention of structural joint damage at one year. Arthritis Rheum 2011;63:609-21.

19. Genentech, Inc. Highlights of prescribing information. San Francisco (CA): Genentech, Inc., 2012; http://www.gene.com/download/pdf/actemra prescribing.pdf.

20. Navarro-Millán I, Singh JA, Curtis JR. Systematic review of tocilizumab for rheumatoid arthritis: a new biologic agent targeting the interleukin- 6 receptor. Clin Ther 2012;34(4):788-802.e3.

21. Thurlings RM, Vos K, Wijbrandts CA, et al. Synovial tissue response to rituximab: mechanism of action and identification of biomarkers of response. Ann Rheum Dis 2008;67:917-25.

22. Edwards JC, Szczepanski L, Szechinski J, et al. Efficacy of B-cell-targeted therapy with rituximab in patients with rheumatoid arthritis. N Engl J Med 2004;350:2572-81.

23. Emery P, Fleischmann R, Filipowicz-Sosnowska A, et al; Dancer Study Group. The efficacy and safety of rituximab in patients with active rheumatoid arthritis despite methotrexate treatment: results of a phase IIB randomized, double-blind, placebo-controlled, dose-ranging study. Arthritis Rheum 2006;54:1390-400.

24. Cohen SB, Emery P, Greenwald MW, et al. Rituximab for rheumatoid arthritis refractory to anti-tumor necrosis factor therapy: results of a multicenter, randomized, double-blind, placebo-controlled, phase III trial evaluating primary efficacy and safety at twenty-four weeks. Arthritis Rheum 2006;54:2793-806.

25. van Assen S, Holvast A, Benne CA, et al. Humoral responses after influenza vaccination are severely reduced in patients with rheumatoid arthritis treated with rituximab. Arthritis Rheum 2010;62:75-81. 
26. Bingham CO III, Looney RJ, Deodhar A. Immunization responses in rheumatoid arthritis patients treated with rituximab: results from a controlled clinical trial. Arthritis Rheum 2010;62:64-74.

27. van Vollenhoven RF, Emery P, Bingham CO III, et al. Long-term safety of patients receiving rituximab in rheumatoid arthritis clinical trials. J Rheumatol 2010;37:558-67.

28. Kremer JM, Westhovens R, Leon M, et al. Treatment of rheumatoid arthritis by selective inhibition of T-cell activation with fusion protein CTLA4Ig. N Engl J Med 2003;349:1907-15.

29. Singh JA, Christensen R, Wells GA, et al. A network meta-analysis of randomized controlled trials of biologics for rheumatoid arthritis: a Cochrane review. CMAJ 2009;181(11):787-96.

30. Kirwan JR. Links between radiological change, disability, and pathology in rheumatoid arthritis. J Rheumatol 2001;28:881-6.

31. Dixon WG, Symmons DP, Lunt M, et al., on behalf of the British Society for Rheumatology Biologics Register. Serious infection following anti-tumor necrosis factor $\alpha$ therapy in patients with rheumatoid arthritis: lessons from interpreting data from observational studies. Arthritis Rheum 2007;56:2896-904.

32. Leombruno JP, Einarson TR, and Keystone EC. The safety of anti-tumour necrosis factor treatments in rheumatoid arthritis: meta and exposureadjusted pooled analyses of serious adverse events. Ann Rheum Dis 2009;68(7):1136-45. Epub 2008 August 27.

33. Bombardier C, Hazelwood GS, Akhaven P, et al. Canadian Rheumatology Association recommendations for the pharmacological management of rheumatoid arthritis with traditional and biologic disease-modifying antirheumatic drugs: part II safety. J Rheum 2012;39:8. doi:10.3899/jrheum.120165.

34. Saag KG, Teng GG, Patkar NM, et al. American College of Rheumatology 2008 recommendations for the use of nonbiologic and biologic diseasemodifying antirheumatic drugs in rheumatoid arthritis. Arthritis Rheum 2008;59(6):762-84.

35. Ledingham J, Deighton C. Update on the British Society for Rheumatology guidelines for prescribing TNF $\alpha$ blockers in adults with rheumatoid arthritis (update of previous guidelines of April 2001). Rheumatology 2005;44:157-63.

36. Nurmohamed NT, Kitas G. Cardiovascular risk in rheumatoid arthritis and diabetes: how does it compare and when does it start? Ann Rheum Dis 2011;70:881-83. doi: 10.1136/ard.2010.145839.

37. Greenberg JD, Kremer JM, Curtis JR, et al., on behalf of the CORRONA Investigators. Extended report: tumour necrosis factor antagonist use and associated risk reduction of cardiovascular events among patients with rheumatoid arthritis. Ann Rheum Dis 2011;70:576-82.

38. Sarzi-Puttini P, Atzeni F, Shoenfeld Y, Ferraccioli G. TNF-alpha, rheumatoid arthritis, and heart failure: a rheumatological dilemma. Autoimmun Rev 2005;4(3):153-61.

39. Westlake SL, Colebatch AN, Baird J, et al. Tumour necrosis factor antagonists and the risk of cardiovascular disease in patients with rheumatoid arthritis: a systematic literature review. Rheumatology 2011;50(3):518-31.

40. Askling J, Fored CM, Brandt L, et al. Risks of solid cancers in patients with rheumatoid arthritis and after treatment with tumour necrosis factor antagonists. Ann Rheum Dis 2005;64:1421-6.

41. Woodrick RS, Ruderman EM. Safety of biologic therapy in rheumatoid arthritis. Nat Rev 2011;7(11):639-52.

42. Geborek P, Bladström A, Turesson C, et al. Tumour necrosis factor blockers do not increase overall tumour risk in patients with rheumatoid arthritis, but may be associated with an increased risk of lymphomas. Ann Rheum Dis 2005;64:699-703.

43. Setoguchi S, Solomon DH, Weinblatt ME, et al. Tumor necrosis factor alpha antagonist use and cancer in patients with rheumatoid arthritis. Arthritis Rheum 2006;54:2757-64.

44. Wolfe F, Michaud K. Biologic treatment of rheumatoid arthritis and the risk of malignancy. Analysis from a large US observational study. Arthritis Rheum 2007;56:2886-95.

45. Widdifield J, Bernatsky S, Paterson JM, et al. Serious infections in a population-based cohort of 86,039 seniors with rheumatoid arthritis. Arthritis Care Res (Hoboken) 2013;65(3):353-61.

46. García-Doval I, Pérez-Zafrilla B, Descalzo MA, et al. Incidence and risk of hospitalization due to shingles and chicken pox in patients with rheumatic diseases treated with TNF antagonists. Ann Rheum Dis 2010;6:1751-5.

47. Strangefield A, Listing J, Herzer P, et al. Risk of herpes zoster in patients with rheumatoid arthritis treated with anti-TNF-alpha agents. JAMA 2009;301:737-44.

48. Bongartz T, Suttin A, Sweetings MJ, et al. Anti-TNF antibody therapy in rheumatoid arthritis and the risk of serious infections and malignancies. JAMA 2006;295:2275-85.

49. Carson KR, Evens AM, Richey EA, et al. Progressive multifocal leukoencephalopathy after rituximab in HIV negative patients: a report of 57 cases from the Research on Adverse Event and Reports project. Blood 2009;113(20):4834-40.

50. Bingham CO III, Looney RJ, Deodhar A. Immunization responses in rheumatoid arthritis patients treated with rituximab: results from a controlled clinical trial. Arthritis Rheum 2010;62:64-74.

51. Rehnberg M, Brisslert M, Amu S, et al. Vaccination response to protein and carbohydrate antigens in patients with rheumatoid arthritis after rituximab treatment. Arthritis Res Ther 2010;12:R111. Epub Jun 8, 2010. 